units, of rationalized spelling of English, and of universally available cheap electric supply.

Walker married in 1903 Miss Eveline Sargent, and they later adopted two boys in whose education and up-bringing they jointly found much pleasure. The boys are now serving in the fighting forces. Walker married in 1935 Miss Valeria D. Ellis, who survives him.

Walker was an untiring author, having served a notable apprenticeship during his association with Sylvanus Thompson. His best-known books are : "The Specification and Design of Dynamo-electric Machinery", "The Diagnosis of Troubles in Dynamoelectric Machinery", "The Control of Speed and Power Factor of Induction Motors", "Conjugate Functions for Engineers". He served as special lecturer at the Imperial College of Science and Technology in 1911, and at the Massachusetts Institute of Technology in 1921 .

A. B. FIELD.

\section{Sir John McFadyean}

WE record with regret the death of Sir John McFadyean, formerly principal of the Royal Veterinary College, who died on February 1 at the age of eighty-seven.

John McFadyean was born on June 17, 1853, the second son of Andrew McFadyean of Barrachan, Wigtownshire. He received his early education at the Ewart Institute and later proceeded to the Royal (Dick) Veterinary College, Edinburgh, from which he was admitted to membership of the Royal College of Veterinary Surgeons in 1876. On obtaining his diploma he was appointed lecturer in anatomy at the College and while so engaged attended classes at the University of Edinburgh as a medical student, graduated bachelor of medicine and master of surgery in 1882 and bachelor of science in the following year. In addition to his teaching in anatomy, McFadyean turned his mind to pathology and bacteriology, subjects then in their infancy. In 1892 the curriculum of veterinary education was extended from three to four years, and far-reaching changes were made in the general standard of education. McFadyean, who had already made a name for himself by his work on tuberculosis, was appointed professor of pathology at the Royal Veterinary College, London, and two years later became principal, which office he held until 1927.

There are few diseases of the domesticated animals to which he has not contributed valuable information, and numerous select committees and Royal Commissions have been largely guided and assisted by his knowledge and experience. He was a tireless worker, and for many years his private researches were carried out during the night hours. In 1888 he founded the Journal of Comparative Pathology and Therapeutics, in which much of his work is recorded.

McFadyean was a great principal and a great man of science; but he will be best remembered by a grateful profession as an equally great teacher, for he possessed eht rare gift of imparting his knowledge to his students in a manner which was readily understandable. By his work he showed nearly half a century ago that there were new and wider fields of veterinary science to be explored. His researches into diseases affecting animals in tropical and sub-tropical countries as well as in Great Britain and in Europe, created what has now come to be known as preventive veterinary medicine and by his teaching he provided the pioneer workers in this new field. We owe it to his sound knowledge and foresight that the veterinary profession was prepared to move in this direction far in advance of official demands.

In 1893 McFadyean was elected a member of Council of the Royal College of Veterinary Surgeons, and was president of that body from 1906 until 1909 and again during $1930-31$ on the occasion of the meeting of the International Veterinary Congress in London, "McFadyean's Congress" as it was called by the eminent foreign delegates who attended from all parts of the world. During the forty-seven years that he served on the Council, McFadyean's personality dominated its deliberations, as it did the field of veterinary science, and the profession owes much of its solid progress through that difficult period to his wide knowledge of men and matters. On his retirement from the principalship of the Royal Veterinary College in 1927 he was elected an honorary associate of the Royal College of Veterinary Surgeons, the highest honour that that body could bestow, and in 1933 he received the first award of the diploma of fellowship honoris causa. After his retirement Sir John pursued his studies with unabated enthusiasm, absorbed almost until the end in his great life-work for veterinary science.

In 1883 he married Mara Eleanor, eldest daughter of Thomas Walley, principal of the Royal (Dick) Veterinary College, Edinburgh. She died in 1929. He leaves three sons and two daughters, to whom we offer our sympathy in their bereavement.

\section{J. B. Buxton.}

\section{Mr. C. Thurstan Holland}

ON November 5, 1897, less than a year after the discovery of X-rays, a paper on the subject was read by Sylvanus Thompson at a meeting which was held to inaugurate the formation of the Roentgen Society. Among those present at this meeting were a few medical men who decided to devote themselves to the application of the new discovery to the needs of medicine. Of this very small band Thurstan Holland was one, and within a few years he had become the most eminent exponent of this new branch of medicine in Great Britain. He was elected president of the Roentgen Society in 1904 and again in 1916. In his address on the latter occasion he wrote: "It is twenty years since I took my first radiograph, twenty years brimful of interest, and of advances which in those days none of us could have even dreamed about, advances which may perhaps be illustrated by the fact that the first successful radiograph I saw taken [by Oliver Lodge in January 1896] was that of a hand, and the exposure was 